\title{
Clinton bill calls for revamp of chronic-disease tracking
}

Virginia Gewin, Washington

Moves are under way to transform the patchy and underfunded system with which US public-health authorities track chronic diseases and their causes.

Plans to upgrade the system were discussed last week at a meeting held at the Institute of Medicine in Washington DC. Delegates have high hopes for the safe passage of the Nationwide Health Tracking Act, which was introduced to Congress last month by Senators Hillary Clinton (Demo-

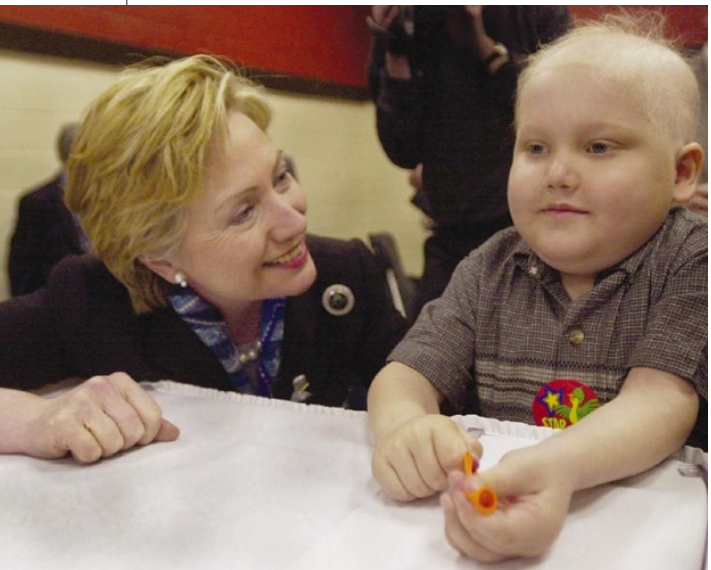

Hillary Clinton, seen here with a leukaemia patient, is pushing for better disease monitoring. crat, New York) and Harry Reid (Democrat, Nevada). It advocates spending \$270 million on a new nationwide environmental-health tracking system to integrate local, state and federal public-health schemes, and is likely to attract bipartisan support. US environmental-health activities are currently split between dozens of agencies.

Chronic diseases such as cancer and asthma are leading causes of death in the United States. "Rising rates of chronic disease require us to act now," Clinton told the meeting.

The need to upgrade the monitoring network was raised in 2000 in a report by the Pew Environmental Health Commission, a publichealth think-tank based at John Hopkins University in Baltimore, Maryland. Monitoring schemes received $\$ 30$ million for the current fiscal year, but experts say that a successful nationwide system would need the larger sum proposed in the Clinton-Reid bill.

The bill proposes establishing five biomedical monitoring laboratories and five environmental-health centres of excellence. The network could also tap into expertise at the Environmental Protection Agency and the US Geological Survey. The latter, for example, already uses remote-sensing satellites to track dust storms that transport heavy metals, pathogens and pesticides.

http://pewenvirohealth.jhsph.edu

\section{Money-spinning journal ruse foiled}

Geoff Brumfiel, Washington

Four scientific societies have rumbled an international scam that is reported to have cost them more than a million dollars.

The operation was run by Eastwood Books, a Los Angeles-based subscription service that renewed subscriptions for university libraries. Manager Jung Shin is alleged to have found a profitable but illicit angle to this mundane service by using fake names and scientific affiliations to purchase individual journal subscriptions. These were then resold to libraries in Asia at institutional rates, which range from two to ten times the individual price.

The four societies - the American Institute of Physics, the American Physical Society, the Institute of Electrical and Electronics Engineers, and the American Chemical Society - announced last week that they had received $\$ 250,000$ in an outof-court settlement after threatening to sue Eastwood Books.

Although this figure is less than their esti-

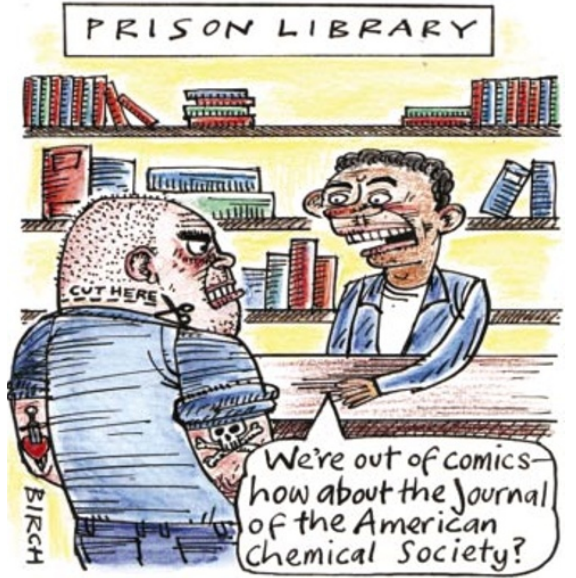

mated losses, the societies are pleased with the outcome. "The main thing was to stop the practice," says Marc Brodsky, executive director of the American Institute of Physics. Shin declined to comment on the matter, but told Nature that she has now left the subscriptions business and resumed her education.

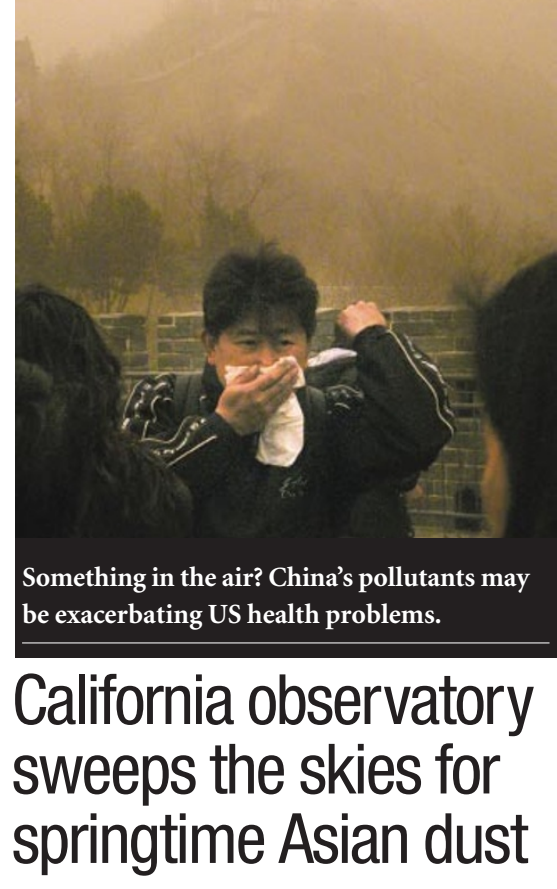

Rex Dalton, Boulder

As the dust clouds that blow across the Pacific Ocean every spring begin their annual journey, a new observatory is gearing up to assess the impacts of the pollution the clouds bring with them.

The National Oceanic and Atmospheric Administration (NOAA) facility at Trinidad Head, an isolated coastal area some $\mathbf{4 0 0}$ kilometres north of San Francisco, should help to determine whether pollutants from Asia are exacerbating health and environmental problems in the United States.

NOAA has similar observatories in Antarctica, Hawaii, Alaska and American Samoa in the Pacific, but only Trinidad Head is in the correct location to monitor the dust arriving at the west coast of the United States. "We really don't understand how dust and chemicals move and mix globally," says atmospheric scientist Russ Schnell, who directs NOAA's observatory operations from its centre in Boulder, Colorado. "The winds are pushing the pollutants of a billion people out of China over the Pacific."

Dust from China is carried across the Pacific by the easterly winds that blow between March and May, bringing chemical pollutants such as ozone. The dust is generated in China by drought, overgrazing of livestock and poor cultivation practices. China is addressing the dust problem, including a massive effort to plant trees as windbreaks.

Two dozen staff are due to start work this month at Trinidad Head, and plan to collaborate with scientists from China, Japan and Korea. They will continuously monitor the dust using radiation detectors, gas chromatographs and mass spectrometers, with further data provided by NOAA aircraft on coastal flights. 